\title{
BELANJA PUBLIK (EXPENDITURE ASSIGNMENT) ANTARA MASALAH DAN EFEKTIVITAS ANGGARAN BELANJA
}

\author{
Neny Ayu Nourmanita ${ }^{1}$
}

\begin{abstract}
This paper discusses the problems of public budgets, particularly in government spending. The discussion will be more emphasized on aspects of government and discussed about the issue of the effectiveness of public spending, especially in the case studies of Magetan district. This paper used qualitative descriptive method. The collection of data obtained through secondary data and analysis document. Data were analyzed with interactive model, through data reduction, data presentation, and conclusion.Discussion of the results shows that overall government spending and areas in Indonesia can not be said to be healthy and in accordance with the needs of the community. Their dominance of indirect expenditure in the form of personnel expenditure sector remains deeply embedded in the budget. Both on the expenditure and the shopping area, both have similarities in personnel expenditure dominance were very swollen. Besides government spending and shopping area cannot provide the impact poverty reduction and improvement of people's welfare.
\end{abstract}

Keywords: Public Expenditure, Government Budgets, APBD, APBN.

\begin{abstract}
ABSTRAK
Tulisan ini membahas mengenai permasalahan anggaran publik, khususnya pada pembelanjaan pemerintah. Pembahasan akan lebih dititik beratkan pada aspek belanja negara/ belanja pemerintah dan dibahas mengenai permasalahan tentang efektivitas belanja publik terutama dengan studi kasus di kabupaten Magetan. Tulisan ini menggunakan metode deskriptif kualitatif. Dimana pengumpulan data diperoleh melalui data sekunder dan telaah dokumen. Data dianalisis dengan model interaktif, melalui reduksi data, penyajian data, dan penarikan kesimpulan. Hasil pembahasan menunjukkan bahwa secara keseluruhan belanja negara maupun belanja daerah di Indonesia belum dapat dikatakan sehat dan sesuai dengan kebutuhan masyarakat. Adanya dominasi belanja tak langsung yang berupa sektor belanja pegawai masih sangat melekat di anggaran belanja. Baik pada belanja negara maupun pada belanja daerah, keduanya memiliki kesamaan dalam dominasi belanja pegawai yang sangat membengkak. Selain itu belanja negara belum dapat memberikan dampak pengurangan kemiskinan dan peningkatan kemakmuran rakyat.
\end{abstract}

Kata kunci: Belanja Publik, Anggaran Pemerintah, APBD.

\footnotetext{
${ }^{1}$ Pascasarjana Manajemen dan Kebijakan Publik, Universitas Gadjah Mada. email: neny.nourmanita@gmail.com
} 


\section{PENDAHULUAN}

Tulisan ini mendiskusikan tentang permasalahan mengenai anggaran publik, khususnya pada pembelanjaan pemerintah. Anggaran negara merupakan inti dari sistem keuangan negara. Anggaran negara merupakan salah satu alat politik fiskal untuk mempengaruhi arah dan percepatan pendapatan nasional. Adapun mengenai anggaran yang akan digunakan tergantung pada keadaan ekonomi yang dihadapi. Dalam keadaan ekonomi yang normal dipergunakan anggaran negara yang seimbang, kemudian dalam keadaan ekonomi yang deflasi biasanya dipergunakan anggaran negara yang defisit dan sebaliknya dalam keadaan ekonomi yang inflasi dipergunakan anggaran negara yang surplus.

Anggaran negara memiliki tiga fungsi utama yang berupa fungsi alokasi, distribusi, dan stabilisasi. Ketiga fungsi ini harus terpenuhi untuk penyelenggaraan anggaran publik yang baik. Dalam anggaran publik, kebijakan anggaran dapat dilihat dari 3 aspek penting anggaran yaitu Pendapatan Negara, Belanja Negara dan Pembiayaan Anggaran. Keterkaitan antara Pendapatan Negara, Belanja Negara dan Pembiayaan
Anggaran dengan fungsi fiskal memiliki hubungan yang kuat dengan peningkatan kesejahteraan rakyat. Aspek yang ada ini tertuang pada anggaran yang disusun setiap tahunnya melalui Anggaran Pendapatan dan Belanja Negara (APBN) maupun Anggaran Pendapatan dan Belanja Daerah (APBD).

Dalam pembahasan ini akan lebih dititik beratkan pada aspek belanja negara/ belanja pemerintah. Belanja pemerintah atau yang dikenal dengan pengeluaran pemerintah, baik di pusat maupun di daerah merupakan salah satu faktor pendorong pertumbuhan ekonomi negara. Belanja publik ini akan digunakan pemerintah baik pusat maupun daerah untuk membiayai segala aktivitas pelayanan dan pembangunan publik bagi kesejahteraan masyarakat. Karena itu, belanja publik yang dikenal sebagai salah satu instrumen kebijakan fiskal, dilakukan pemerintah di samping pos pendapatan pemerintah. Semakin besar belanja publik yang dikeluarkan maka, yang diharapkan adalah makin meningkatkan kegiatan perekonomian, baik di pusat maupun di daerah (terjadi investasi pada bidang perekonomian). Di sisi lain, semakin besar pendapatan yang dihasilkan dari pajak 
atau penerimaan penerimaan yang bersumber dari masyarakat, maka akan mengakibatkan menurunnya kegiatan perekonomian.

Namun, selama ini permasalahan mengenai pembelanjaan publik ini masih menjadi persoalan yang besar di Indonesia. Baik belanja publik pemerintah pusat melalui Anggaran Pendapatan dan Belanja Negara (APBN) maupun belanja pemerintah daerah melalui Anggaran Pendapatan dan Belanja Daerah, keduanya memiliki persoalan yang krusial. Permasalahan yang terjadi meliputi efisiensi dan efektivitas belanja publik, korupsi pada anggaran belanja publik, dan dampak belanja publik terhadap pengurangan kemiskinan dan peningkatan kemakmuran rakyat, serta penyerapan anggaran dalam belanja publik, menjadi persoalan yang harus segera diselesaikan oleh Pemerintah. Fokus pembahasan ini hanya akan dibahas mengenai permasalahan tentang efektivitas belanja publik terutama dengan studi kasus di kabupaten Magetan.

Dalam penyelenggaran kegiatan pemerintahan, sangat diperlukan adanya pembiayaan keuangan negara agar dalam pelaksanaan kegiatan berjalan lancar sesuai dengan target dan tujuan yang ingin dicapai. Pembiayaan keuangan negara akan lebih terarah apabila dilakukan perumusan anggaran untuk menentukan rencana kegiatan dengan sumber pendapatan yang diperoleh. Anggaran publik ini penting dilakukan, mengingat dengan anggaran ini, maka akan membantu pemerintah untuk menentukan tingkat kebutuhan masyarakat dalam pengalokasian uang negara.

Anggaran digunakan pemerintah sebagai alat untuk mengarahkan pembangunan sosial-ekonomi, menjamin kesinambungan, dan meningkatkan kualitas hidup masyarakat. Selain itu anggaran diperlukan karena adanya kebutuhan dan keinginan masyarakat yang tak terbatas dan terus berkembang, sedangkan sumber daya yang ada terbatas. Anggaran diperlukan karena adanya masalah keterbatasan sumber daya (scarcity of resources), pilihan (choice), dan trade offs. Anggaran diperlukan untuk meyakinkan bahwa pemerintah telah bertanggung jawab terhadap rakyat. Dalam hal ini anggaran publik merupakan instrumen pelaksanaan akuntabilitas publik oleh lembaga-lembaga publik yang ada (Mardiasmo, 2005). Dengan demikian, anggaran publik dapat digunakan sebagai alat ukur atas 
kebijakan pemerintah dalam mengambil mensejahterakan rakyatnya.

Dalam melaksanakan fungsi alokasi, pemerintah menyediakan barang-barang publik yang ditujukan untuk mengalokasikan sumber daya yang ada untuk memenuhi kepentingan bersama. Hal yang dilakukan yaitu dengan melakukan pendanaan untuk berbagai program dan kegiatan dan investasi, seperti belanja untuk penyediaan berbagai infrastruktur, maupun untuk membiayai berbagai pengeluaran atau belanja barang dan jasa (konsumsi) pemerintah. Dalam menjalankan fungsi distributif negara berperan dalam mengatur distribusi pendapatan dan kesejahteraan masyarakat yang slah satunya diwujudkan dalam bentuk pajak. Hal yang dilakukan yaitu dengan pemberdayaan kelompok masyarakat yang berpenghasilan rendah, kurang beruntung atau berkemampuan ekonomi terbatas dengan membentuk program-program pemberdayaan maupun program bantuan.

Program bantuan misalnya berupa Program Nasional Pemberdayaan Masyarakat (PNPM), Bantuan Operasional Sekolah (BOS), Gerakan Nasional Orang Tua Asuh (GNOTA), Jaminan Kesehatan Masyarakat
(Jamkesmas), dan lain-lain. Kemudian dalam fungsi stabilisasi pemerintah menjaga stabilitas ekonomi melalui keseimbangan antara uang dan barang maupun jasa yang beredar. Hal yang dilakukan pemerintah yaitu dalam bentuk melakukan subsidi terhadap beberapa kebutuhan pokok masyarakat, misalnya subsidi kebutuhan sembilan bahan pokok (sembako) dan subsidi Bahan Bakar Minyak (BBM).

Dalam pembentukan anggaran, pemerintah Indonesia melakukan perumusan setiap satu tahun sekali dengan mengajukan Anggaran Pendapatan dan Belanja Negara (APBN) dari Presiden untuk disetujui oleh Dewan Perwakilan Rakyat (DPR). APBN berisikan daftar sistematis dan terperinci yang memuat rencana penerimaan dan pengeluaran negara dalam satu tahun anggaran. Pola APBN dan realisasinya adalah untuk melaksanakan tugas sehari-hari (rutin) dalam rangka pelaksanaan kegiatan dibidang pemerintahan. APBN mempunyai fungsi otorisasi, perencanaan, pengawasan, alokasi, distribusi, dan stabilisasi. Fungsi otorisasi mengandung arti bahwa APBN menjadi dasar untuk melaksanakan pendapatan dan belanja pada tahun yang bersangkutan. 
Fungsi perencanaan mengandung arti bahwa APBN menjadi pedoman bagi manajemen dalam merencanakan kegiatan pada tahun yang bersangkutan. Fungsi pengawasan mengandung arti bahwa APBN menjadi pedoman untuk menilai apakah kegiatan penyelenggaraan pemerintahan sesuai dengan ketentuan yang telah ditetapkan. Fungsi alokasi mengandung arti bahwa APBN harus diarahkan untuk menciptakan lapangan kerja/mengurangi pengangguran dan pemborosan sumber daya, serta meningkatkan efisiensi dan efektivitas perekonomian. Fungsi distribusi mengandung arti bahwa kebijakan APBN harus memperhatikan rasa keadilan dan kepatutan. Fungsi stabilisasi mengandung arti bahwa APBN menjadi alat untuk memelihara dan mengupayakan keseimbangan fundamental perekonomian negara.

Semua penerimaan yang menjadi hak dan pengeluaran yang menjadi kewajiban negara dalam tahun anggaran yang bersangkutan harus dimasukkan dalam APBN. Dalam APBN berisikan rincian penerimaan negara dan rincian pengeluaran pemerintah yang berupa belanja negara, serta pembiayaan pemerintah. Penerimaan negara meliputi penerimaan dalam negeri yaitu berupa penerimaan perpajakan, dan penerimaan negara bukan pajak, serta penerimaan hibah. Penerimaan negara baik dari dalam negeri ataupun yang berasal dari luar negeri sangat penting bagi proses keberhasilan proses pembangunan nasional, terutama penerimaan pemerintah dari dalam negeri yaitu berupa penerimaan pajak dan bukan pajak serta penerimaan migas dan non migas.

Sedangkan belanja negara atau pengeluaran pemerintah berupa Belanja Pegawai, Belanja Barang, Belanja Modal, Bunga, Subsidi, Hibah, Bantuan Sosial, dan Belanja Lain-lain serta tranfer ke daerah yang berupa pemberian dana alokasi umum maupun dana alokasi khusus pada daerah. Belanja negara dipergunakan untuk keperluan penyelenggaraan tugas pemerintahan pusat dan pelaksanaan perimbangan keuangan antara pemerintah pusat dan daerah.

Otonomi daerah yang berlaku di Indonesia dengan dikeluarkannya Nomor 32 Tahun 2004 tentang otonomi daerah dan berlaku hingga saat ini dimaksudkan untuk memberikan sebagian kewenangan pemerintah pusat kepada daerah untuk mengatur dan mengurus rumah tangganya sendiri. Pemberian otonomi daerah ini 
juga diikuti oleh pemberian kewenangan dalam hal keuangan atau otomoney. Hal ini menyebabkan pemerintah daerah dituntut untuk memaksimalkan potensi sumber daya keuangan yang dimiliki daerah untuk mendukung penyelenggaraan pemerintahan. Daerah, seperti halnya pemerintah Pusat harus membuat rancangan anggaran keuangan untuk memetakan penerimaan daerah serta kebutuhan belanja daerah dalam penyelenggaraan pemerintahan di daerah. Anggaran Pendapatan dan Belanja Daerah merupakan rencana keuangan tahunan pemerintah daerah yang dibahas dan disetujui bersama oleh pemerintah daerah dan DPRD serta ditetapkan dengan Peraturan Daerah (UU No. 32 Tahun 2004).

Selain merupakan rencana keuangan tahunan pemerintah daerah, APBD juga merupakan instrumen dalam rangka mewujudkan pelayanan dan peningkatan kesejahteraan masyarakat untuk tercapainya tujuan bernegara. Lingkup anggaran menjadi relevan dan penting di lingkungan pemerintah daerah. Hal ini terkait dengan dampak anggaran terhadap kinerja pemerintah, sehubungan dengan fungsi pemerintah dalam memberikan pelayanan kepada masyarakat.
Sama halnya dengan APBN, didalam struktur APBD terdiri dari tiga aspek, yaitu pendapatan daerah, belanja daerah dan pembiayaan. Penerimaan yang dimiliki daerah terdiri atas pendapatan daerah dan pembiayaan. Pendapatan daerah sendiri terdiri dari Pendapatan Asli Daerah (PAD); Dana Perimbangan; dan Lain-lain Pendapatan. Aspek belanja daerah terdiri dari belanja pegawai, belanja barang/ jasa, dan belanja modal. Sedangkan komponen pembiayaan terdiri atas Sisa lebih perhitungan anggaran TA sebelumnya (SiLPA), pencairan dana cadangan, hasil penjualan kekayaan daerah yang dipisahkan, penerimaan pinjaman daerah, penerimaan kembali pemberian pinjaman, penerimaan piutang daerah.

\section{METODE}

Tulisan ini menggunakan pendekatan kualitatif. Dimana pengumpulan data diperoleh melalui data sekunder dengan telaah dokumen. Data dianalisis dengan model interaktif, melalui reduksi data, penyajian data, dan penarikan kesimpulan. Kajian yang ada didukung dengan beberapa data empiris dan dielaborasikan untuk dapat menggambarkan efektifitas belanja publik. 
HASIL DAN PEMBAHASAN

Kondisi Belanja negara Indonesia:

Permasalahan yang di hadapi

Dalam pelaksanaan penganggaran publik di Indonesia selama ini telah berjalan secara terbuka dengan menggunakan prinsip anggaran berbasis kinerja. Prinsip penganggaran ini dilakukan dengan mengaitkan setiap biaya yang dituangkan dalam kegiatan-kegiatan dengan manfaat yang dihasilkan. Namun, meski telah menerapkan prinsip ini, pada kenyataannya anggaran yang ada selama ini masih belum menyentuh kebutuhan masyarakat. Kebutuhan tersebut baik berupa kebutuhan mendasar bagi masyarakat seperti pendidikan, kesehatan, layanan sosial serta peningkatan kesejahteraan masyarakat secara merata. APBN yang selama ini dibentuk oleh pemerintah belum berpihak pada kebutuhan masyarakat. Hal ini dibuktikan dengan masih tingginya belanja pemerintah dalam pembiayaan belanja tak langsung berupa belanja pegawai dibandingkan dengan pembiayaan dalam aspek barang/ jasa bahkan pada aspek belanja modal.

Setiap tahun anggaran publik masih terbebani dengan anggaran belanja pegawai yang cukup besar melebihi anggaran yang digunakan untuk belanja modal. Terlebih pada tahun 2013, kenaikan yang cukup besar terjadi pada setiap anggaran belanja pemerintah. Tiap tahunnya anggaran belanja modal pemerintah pusat meskipun mengalami kenaikan besaran anggaran, namun masih belum lebih besar dari anggaran belanja pegawai. Permasalahan lain terkait dengan belanja negara yaitu pelum maksimalnya penyerapan anggaran pemerintah. Selama ini penyerapan anggaran pemerintah tidak sesuai dengan target dan jadwal pemerintah dalam pengalokasian anggaran. Penyerapan anggaran hingga 7 Juni 2013 baru mencapai Rp 541,9 triliun atau $32,2 \%$ dari pagu yang ditetapkan dalam APBN tahun 2013 sebesar Rp 1.683 triliun. Realisasi serapan anggaran ini lebih rendah dibandingkan periode yang sama pada tahun lalu, yakni $34,1 \%$. Penyerapan belanja yang hanya 32,2\% itu juga jauh di bawah target pemerintah, yakni $40 \%$.

Pada dua tahun terakhir, realisasi belanja modal dalam APBN terbilang rendah. Realisasi belanja modal pada tahun 2013 bahkan jauh lebih rendah di bandingkan tahun sebelumnya. Bila per 7 Juni 2012 realisasi belanja modal sudah mencapai 16,4\% maka per 7 Juni 2013 belanja modal baru terserap 14,4\% (Rp 26,55 triliun), sekedar kilas balik, 
anggaran 2009 hanya terserap 91,8 persen, lalu menjadi $90,9 \%$ pada 2010. Dua tahun berikutnya, penyerapan anggaran berkisar pada $87 \%$. Penyerapan anggaran yang tidak optimal $100 \%$ baik pada tingkat pusat maupun daerah menjadikan penumpukan anggaran pada akhir tahun dan tidak terpakainya anggaran (idle cash). Hal ini menyebabkan terjadinya penggunaan anggaran yang sia-sia yang justru digunakan oleh pemerintah dalam pengadaan program-program yang tak terencana untuk menghabiskan anggaran yang terlanjur dibuat. Selain itu dapat diketahui pada simpanan yang dimiliki daerah pada bank-bank daerah maupun umum karena sisa anggaran yang tidak terpakai.

Selama ini permasalahan yang banyak dikeluhkan masyarakat dan perlu untuk mendapatkan perhatian pada saat ini adalah terkait ketersediaan infrastruktur untuk mendorong kegiatan dan pemerataan hasil-hasil pembangunan. Hal ini merupakan tantangan tersendiri bagi upaya pemerintah untuk mewujudkan pembangunan yang merata.

Pemerataan masih dirasakan kegiatan pertumbuhan yang masih terpusat di daerah tertentu, sementara daerah lain masih belum mampu mengoptimalkan potensi ekonomi daerahnya. Permasalahan tersebut antara lain disebabkan daya dukung infrastruktur untuk menopang perkembangan kegiatan ekonomi belum tersedia secara memadai di seluruh wilayah secara merata. Pentingnya peran infrastruktur yang memadai dalam pencapaian sasaran pembangunan dapat terlihat dalam beberapa hal sebagai berikut. Infrastuktur, khususnya jaringan transportasi antar daerah, akan meningkatkan keterkaitan dan keterhubungan antar daerah di Indonesia. Hal ini diharapkan mampu menciptakan peluang dan kesempatan yang lebih besar bagi pengembangan kegiatan ekonomi masyarakat serta aktivitas produksi.

Peningkatan aktivitas ekonomi dan produksi akan menciptakan kesempatan dan peluang kerja, peningkatan pendapatan, perbaikan taraf hidup dan peningkatan kesejahteraan masyarakat. Infrastruktur yang mendukung perbaikan komunikasi dan transportasi antar wilayah di Indonesia akan menciptakan peluang pasar yang lebih besar bagi dunia usaha. Di samping itu, ketersediaan infrastruktur yang merata akan lebih memberikan jaminan yang lebih baik bagi penyebaran hasil-hasil pembangunan ke seluruh wilayah dan masyarakat, khususnya bagi masyarakat di wilayah-wilayah terluar dan 
terpencil. Pemerataan hasil pembangunan dan distribusi yang lebih merata akan memberikan dampak positif bagi upaya pengendalian inflasi di berbagai wilayah negara, yang juga merupakan faktor penting bagi upaya menjaga tingkat pendapatan riil masyarakat.

Dari kondisi belanja negara yang masih mengalami permasalahan tersebut maka dapat diketahui bagaimana kondisi belanja negara saat ini. Kondisi belanja negara saat ini jauh untuk bisa dikatakan sehat. Hal ini selain dikarenakan banyaknya persoalan terkait dengan belanja negara, juga dipengaruhi oleh masih didominasinya belanja negara saat ini dalam aspek belanja tak langsung yang berupa belanja pegawai.

Belanja negara Indonesia banyak digunakan untuk membiayai gaji para Pegawai Negeri Sipil (PNS). Padahal kinerja banyak dari PNS tersebut yang kurang maksimal atau bahkan cenderung mengecewakan. Para PNS yang di gadang-gadang sebagai abdi masyarakat pada kenyataannya justru banyak yang tidak produktif dan tidak benar-benar bekerja seperti tugas yang seharusnya. Ketidaksesuaian antara anggaran belanja pegawai yang dianggarkan dengan kinerja PNS ini membuat belanja negara menjadi tidak sehat karena terjadi pemborosan yang luar biasa besar.

Anggaran belanja negara saat ini juga sangat tidak sesuai dengan apa yang dibutuhkan masyarakat. Belanja negara yang masih didominasi oleh belanja tak langsung dari pada belanja langsung pada aspek belanja pegawai dan kecilnya sektor belanja modal dan belanja barang/jasa menjadikan belanja negara tidak memilki keberpihakan kepada masyarakat. Salah satu peningkatan kemakmuran masyarakat hanya dapat didorong oleh anggaran publik, dimana belanja modal (capital spending) terus ditambah dan dikelola dengan baik. Namun, struktur APBN saat ini menunjukkan bahwa belanja modal sangat sulit ditingkatkan. Salah satunya dibebani oleh belanja tak langsung yang berupa belanja pegawai yang tinggi.

Belanja negara yang sesuai dengan kebutuhan masyarakat adalah belanja negara yang lebih memprioritaskan pada aspek belanja modal. Dimana belanja modal ini dapat dipergunakan oleh negara untuk membangun infrastruktur bagi masyarakat. Infrastruktur dapat berupa bangunan sekolah, jembatan, jalan raya, sistem irigasi, jaringan, dan sebagainya yang dapat dimanfaatkan masyarakat untuk pemerataan hasil pembangunan. 
Infrastruktur yang memadai juga dapat mendorong peningkatan ekonomi di daerah-daerah, mendekatkan komunikasi dan transportasi antar wilayah di Indonesia yang berupa kepulauan.

Cara terbaik untuk meningkatkan kesejahteraan masyarakat atau hal yang seharusnya dilakukan pemerintah dengan kondisi belanja negara saat ini yaitu dengan membuat kebijakan anggaran yang tepat yaitu dengan membuat kebijakan anggaran yang pro rakyat. Maksudnya disini adalah dengan menyeimbangkan pendapatan (baik negara/ daerah) dengan kebutuhan yang diperlukan. Misalnya apabila difokuskan pada hal belanja negara/ daerah maka perlu untuk melakukan menekan anggaran belanja pegawai. Memang tidak mungkin untuk mengurangi gaji pegawai yang selama ini jumlahnya terus membengkak, namun dapat dilakukan dengan menekan pengeluaran dalam pemberian honorarium maupun biaya perjalanan dinas bagi pegawai.

Disamping itu, dengan lebih meningkatkan belanja modal pemerintah agar pembangunan infrastruktur bagi masyarakat terus meningkat. Hal ini karena belanja modal pemerintah yang berupa pembelian aset nilainya jangka panjang dan lebih dari 12 bulan sehingga akan efektif apabila ditingkatkan besaran anggaran untuk peningkatan kemakmuran publik.

\section{Kondisi Belanja Daerah: Studi Kasus di \\ Kabupaten Magetan}

Sama halnya dengan belanja negara, secara umum kondisi belanja daerah juga mengalami permasalahan. Permasalahan yang dihadapi dalam belanja daerah adalah masih dominannya belanja tidak langsung dibandingkan belanja langsung dalam komposisi belanja daerah. Akibatnya, belanja langsung yang digunakan untuk meningkatkan kuantitas dan kualitas pemenuhan hak layanan dasar dalam pelayanan publik bagi masyarakat belum optimal.

Selain itu masalah yang menyangkut anggaran di daerah yaitu korupsi yang terjadi di tingkat daerah dalam penggunaan anggaran belanja. Dana APBD banyak digunakan untuk politik uang bagi para pejabat, biaya prosedural politik dan dana lain-lain. Selain itu bentuk korupsi yang dilakukan di daerah yaitu berupa banyaknya kepala daerah yang menggunakan dana APBD untuk kepentingan pribadi dan kelompoknya maupun bersama pihak swasta yang menjadi rekanan bisnis atau proyek penyelewengan anggaran. 
Dari permasalahan yang ada di daerah, menjadikan pertanyaan yang perlu untuk dijawab, mengenai bagaimana efektivitas belanja daerah melalui APBD yang ada? apakah sesuai dengan kebutuhan daerah yang bersangkutan dalam pembangunan yang diharapkan pada daerah yang bersangkutan?. Untuk menjawab pertanyaan mengenai efektivitas APBD melalui rincian tiga komponen dalam anggaran belanja langsung, yaitu belanja pegawai, belanja modal, dan belanja barang/jasa perlu dilakukan analisis terhadap suatu daerah. Untuk itu akan dilakukan studi kasus dengan melakukan analis pada APBD Kabupaten Magetan.
Berdasarkan profil APBD Kabupaten Magetan tahun 2014 yang menunjukkan pendapatan yang diperoleh sebesar Rp. 1.340.179.611.736,00. Sedangkan besaran jumlah belanja seluruhnya sebesar Rp.1.403.496.525.571,00 yang terdiri dari belanja tidak langsung sebesar Rp.905.060.206.071,00 dan belanja langsung sebesar Rp.498.436.319.500,00. Hal ini menunjukkan APBD tersebut diketahui mengalami defisit anggaran sebesar Rp.63.316.913.835,00. Data ringkasan APBD Kabupaten Magetan sebagai berikut:

Tabel Data APBD TA 2014 *)

(dalam jutaan rupiah)

\begin{tabular}{|c|c|}
\hline \multicolumn{1}{|c|}{ Uraian } & Kab. Magetan \\
\cline { 2 - 2 } & $\mathbf{1}$ \\
\hline Pendapatan & 1.340 .180 \\
\hline PAD & 112.759 \\
\hline Dana Perimbangan & 945.286 \\
\hline Lain-lain Pendapatan Daerah yang Sah & 282.135 \\
\hline Belanja & 1.403 .497 \\
\hline Belanja Tidak Langsung & 905.060 \\
\hline Belanja Langsung & 498.436 \\
\hline Belanja Pegawai & 21.190 \\
\hline Belanja Barang dan jasa & 254.563 \\
\hline Belanja Modal & 222.684 \\
\hline Pembiayaan Netto & 63.317 \\
\hline Pengeluaran Pembiayaan & 16.500 \\
\hline
\end{tabular}

*) Keterangan:

Data per 30 Maret 2014

Data sangat sementara 
Data tersebut sebelumnya dapat dilakukan analisis efektivitas APBD pada Kabupaten Magetan yaitu bahwa APBD tersebut belum dapat dikatakan efektif. Hal ini dilihat dari alokasi belanja tidak langsung berupa gaji pegawai masih sangat tinggi daripada alokasi pada belanja langsungnya. Padahal belanja langsung berupa honorarium pegawai, belanja barang/ jasa dan belanja modal lebih penting dan dibutuhkan masyarakat untuk digunakan dalam kegiatan-kegiatan ekonomi untuk mendorong pertumbuhan ekonomi daerah.

Efektivitas anggaran daerah dapat diketahui dengan seberapa besar pemerintah daerah mengalokasikan besaran nilai belanja untuk kepentingan publik yang dapat digunakan secara optimal untuk kegiatan ekonomi demi kesejahteraan masyarakat. Dalam permendagri dalam pedoman penyusunan APBD juga telah dijelaskan bahwa dalam penyusunan APBD harus ditekankan pada keberpihakan pada kepentingan masyarakat (publik) yang berupa belanja langsung daripada kepentingan aparatur (belanja tidak langsung).

Belanja modal kabupaten Magetan yang hanya sebesar 222.683.607.134,00 menunjukkan bahwa pengeluaran daerah masih relatif rendah. Hal ini berarti efektivitas penggunaan anggaran untuk meningkatkan kesejahteraan masyarakat di kabupaten Magetan juga masih relatif kecil dan menghambat pertumbuhan ekonomi daerah. Kemudian apabila dilihat dari besarnya anggaran belanja barang/jasa, anggaran sebesar Rp. 254.562.992.866,00 menunjukkan bahwa pemkab masih cenderung konsumtif dalam pengadaan barang dan jasa.

Penyerapan anggaran daerah banyak dialokasikan untuk pengadaan barang/jasa. Seharusnya pengadaan barang dan jasa ini dilakukan dengan melakukan evaluasi dan pengkajian terhadap barang-barang inventaris yang tersedia baik dari sisi kondisi maupun umur ekonomisnya sehingga pengadaan barang inventaris dapat dilakukan secara selektif sesuai kebutuhan masing-masing Satuan Kerja Perangkat Daerah (SKPD).

Namun, apabila dilihat rincian anggaran belanja barang/ jasa ini ternyata masih didominasi belanja barang/ jasa bagi kepentingan pegawai pemkab sendiri. Belanja kepentingan barang pegawai ini berupa penggunaan fasilitas bagi pegawai berupa pemeliharaan kendaraan dinas, biaya bensin, maupun asuransi kesehatan bagi PNS. Hal ini 
tentu saja tidak berpengaruh dalam peningkatan kesejahteraan masyarakat. Sehingga efektivitas anggaran belanja barang/jasa masih terlampau besar yang dianggarkan dan belum cukup efektif untuk meningkatkan kesejahteraan publik.

Dari analisis efektivitas anggaran diatas maka dapat diketahui bahwa anggaran yang demikian tersebut cenderung tidak sehat dan kurang efektif karena belanja pemkab masih sangat terbebani oleh belanja pegawai dan mengesampingkan belanja modal untuk peningkatan kesejahteraan publik. Sehingga kesejahteraan masyarakat di kabupaten Magetan masih sulit untuk ditingkatkan apabila anggaran daerah masih dibebani belanja pegawai yang besaran anggarannya cenderung besar.

Seharusnya dilakukan peningkatan belanja modal dengan mengurangi belanja pegawai yang berupa tunjangan dan belanja baran/jasa yang hanya untuk fasilitas pegawai pada besaran belanja tidak langsung tersebut. Dengan meningkatkan belanja modal maka infrastruktur kabupaten dapat ditingkatkan dan investasi daerah dapat meningkat untuk kesejahteraan masyarakat.
Belanja modal yang besaran anggarannya hanya sebesar 222.683.607.134,00 akan menjadikan kurangnya infrastruktur yang ada di kabupaten Magetan. Kondisi ini akan mempersulit akses masyarakat untuk memperoleh hak-hak pelayanan dasar yang seharusnya mereka miliki. Hak pelayanan dasar tersebut berupa layanan kesehatan, pendidikan, dan pelayanan sosial.

Maupun dalam layanan admisnistrasi yang berupa perijinan, akta maupun lisensi yang kewenangannya diatur dan dikeluarkan oleh kabupaten yang bersangkutan. Selain melakukan analisis mengenai efektivitas belaja daerah Kabupaten Magetan melalui APBD yang dimiliki, maka dapat pula dilihat kesesuaian kebutuhan kabupaten dengan alokasi dana pada masing-masing dinas yang ada, data disajikan dalam Tabel 2.

Dari data tersebut menunjukkan bahwa dalam pengalokasian besaran belanja pemerintah daerah sesuai dengan urusan pemerintahan, alokasi pada dinas yang mengurusi tentang pelayanan dasar mendapat porsi yang sesuai. Dimana porsi yang sesuai ini artinya mendapatkan porsi yang relatif cukup besar dibandingkan dengan dinas pengelola 
Tabel 2. Ringkasan Jumlah Belanja Kabupaten Magetan

\begin{tabular}{|c|c|}
\hline \multirow{2}{*}{ URUSAN PEMERINTAH DAERAH } & Kab. Magetan \\
\hline & Jumlah Belanja \\
\hline Urusan Wajib & 1.311.794.432.556 \\
\hline Pendidikan & 653.018 .707 .863 \\
\hline Kesehatan & 161.417 .360 .818 \\
\hline Pekerjaan Umum & 138.500 .487 .192 \\
\hline Perumahan & 8.450 .000 .000 \\
\hline Penataan Ruang & 950.000 .000 \\
\hline Perencanaan Pembangunan & 6.349 .444 .200 \\
\hline Perhubungan & 15.932 .379 .975 \\
\hline Lingkungan Hidup & 15.715 .095 .850 \\
\hline Kependudukan dan Pencatatan Sipil & 5.082 .193 .850 \\
\hline $\begin{array}{l}\text { Pemberdayaan Perempuan dan Perlindungan } \\
\text { Anak }\end{array}$ & 370.000 .000 \\
\hline Keluarga Berencana dan Keluarga Sejahtera & 10.718.220.609 \\
\hline Sosial & 6.375 .452 .000 \\
\hline Ketenagakerjaan & 500.816 .000 \\
\hline Koperasi dan Usaha Kecil Menengah & 3.516 .319 .000 \\
\hline Penanaman Modal & 1.590 .000 .000 \\
\hline Kebudayaan & 1.963 .000 .000 \\
\hline Pemuda dan Olahraga & 8.223 .323 .750 \\
\hline Kesatuan Bangsa dan Politik Dalam Negeri & 17.226.618.200 \\
\hline $\begin{array}{l}\text { Otonomi Daerah, Pemerintahan Umum, } \\
\text { Administrasi Keuangan Daerah, Perangkat } \\
\text { Daerah, Kepegawaian dan Persandian }\end{array}$ & 239.378.837.724 \\
\hline Ketahanan Pangan & 6.145 .475 .575 \\
\hline Pemberdayaan Masyarakat dan Desa & 6.593 .741 .600 \\
\hline Statistik & 175.000 .000 \\
\hline Kearsipan & 345.000 .000 \\
\hline Komunikasi dan Informatika & 1.491 .974 .950 \\
\hline Perpustakaan & 1.764 .983 .400 \\
\hline Urusan Pilihan & 91.702.093.015 \\
\hline Pertanian & 47.786 .425 .891 \\
\hline Kehutanan & 8.065 .971 .450 \\
\hline Energi dan Sumber Daya Mineral & 160.000 .000 \\
\hline Pariwisata & 8.329 .200 .770 \\
\hline Kelautan dan Perikanan & 3.451 .223 .400 \\
\hline Perdagangan & 3.996 .999 .000 \\
\hline Industri & 19.421 .772 .504 \\
\hline Ketransmigrasian & 490.500 .000 \\
\hline Jumlah Belanja & 1.403.496.525.571 \\
\hline
\end{tabular}

Sumber: Kabupaten Magelang (2015)

pelayanan yang bukan merupakan pelayanan dasar bagi masyarakat. Pada dinas yang memberikan pelayanan dasar seperti pendidikan mendapatkan jumlah anggaran belanja sebesar Rp.653.018.707.863,00 urusan pelayanan dasar kedua berupa kesehatan mendapat jatah alokasi anggaran belanja sebesar 
Rp.161.417.360.818,00 dan urusan pekerjaan umum yang mengurus dalam hal infrastruktur jalan jembatan mendapatkan alokasi belanja sebesar Rp. 138.500.487.192,00 ketiga urusan ini merupakan urusan pelayanan dasar yang sangat dibutuhkan masyarakat telah mendapatkan porsi yang cukup sesuai dengan apa yang di emban oleh dinas terkait.

Namun, yang menjadi poin penting yang perlu dicermati adalah pada sektor pelayanan dasar seperti kependudukan dan pencatatan sipil, dinas sosial, keluarga berencana, perumahan, ketahanan pangan dan bahkan ketenaga kerjaan justru proporsi jumlah anggaran belanja yang diterima cenderung lebih kecil atau bahkan sangat kecil dibandingkan dengan sektor urusan kesatuan bangsa dan politik dalam negeri serta urusan otonomi daerah, pemerintahan umum, administrasi keuangan daerah, perangkat daerah kepegawaian dan persandian. Dua urusan terakhir tersebut mendapat proporsi belanja yang sangat besar dan bahkan cenderung tidak wajar sebesar Rp.17.226.618.200,00 dan Rp.239.378.837.724,00. Padahal kedua urusan tersebut tidak banyak bersinggungan langsung dengan kepantingan dasar masyarakat, justru pelayanan dalam perijinan, lisensi, ataupun pembuatan akta pada dinas kependudukan misalnya yang langsung berhubungan dengan kebutuhan masyarakat.

Besarnya anggaran tersebut sebaiknya dilakukan perombakan dan dialokasikan pada sektor yang lain. Karena apabila tidak, maka akan menimbulkan korupsi yang mau tidak mau akan terjadi karena besaranya anggaran tidak sesuai dengan kebutuhan dan kenyataannya dilapangan yang dibutuhkan masyarakat dalam hal pelayanan. Anggaran belanja yang tidak wajar ini sebaiknya dialokasikan pada beberapa urusan pilihan yang ada. Apabila dicermati, urusan pilihan yang ada pada kabupaten magetan menunjukkan potensi yang ada di kabupaten ini yaitu pada sektor pertanian. Kemudian pendukungnya yaitu pada sektor industri. Potensi kabupaten magetan yang berada pada sektor pertanian sudah seharusnya mendapatkan perhatian yang besar untuk meningkatkan perekonomian dan kesejahteraan masyarakat di Magetan.

Hal yang perlu diperhatikan disini yaitu apabila sektor pertanian menjadi 
sektor yang utama di Kabupaten Magetan maka tentu saja sektor pangan juga harus dikedepankan untuk mendapatkan anggaran belanja yang besar. Namun, apabila dilihat pada urusan wajib, anggaran belanja daerah pada urusan ketahanan pangan mendapatkan proporsi anggaran belanja yang kecil, yaitu hanya sebesar Rp.6.145.475.575,00. Seharusnya anggaran untuk ketahanan pangan juga saling terkait dengan sektor pertanian, karena usaha melakukan ketahanan pangan di kabupaten magetan harus ditingkatkan. Jika sektor pertanian tinggi namun dari sektor dinas yang mengurusi atau berwenang dalam hal ketahan pangan tidak melakukan upaya dikarenakan kurangnya anggaran belanja pada dinas terkait, maka hal tersebut tentu akan percuma.

Maka, untuk menjawab pertanyaan "Apakah prioritas belanja di daerah sudah sesuai dengan kebutuhan pembangunan di daerah yang bersangkutan?" jika dicermati sesuai dengan studi kasus pada daerah di kabupaten magetan tersebut jawabannya adalah belum sesuai. Hal ini dikarenakan di kabupaten magetan, proporsi belanja daerah selain masih didominasi oleh belanja tak langsung pada sektor belanja pegawai dan rendahnya belanja modal dan barang/jasa. Juga diakibatkan dari belum sesuainya anggaran yang ditetapkan dalam pengalokasian anggaran belanja sesuai dengan potensi dan kebutuhan yang diperlukan oleh masyarakat di Kabupaten Magetan.

\section{SIMPULAN}

Secara keseluruhan belanja negara maupun belanja daerah di Indonesia belum dapat dikatakan sehat dan sesuai dengan kebutuhan masyarakat. Hal ini disebabkan masih banyaknya persoalan yang masih belum mampu diatasi oleh pemerintah. Adanya dominasi belanja tak langsung yang berupa sektor belanja pegawai masih sangat melekat di anggaran belanja kita. Baik pada belanja negara maupun pada belanja daerah, keduanya memiliki kesamaan dalam dominasi belanja pegawai yang sangat membengkak. Persoalan lain yaitu belum terserapnya anggaran belanja pemerintah pusat maupun daerah dengan baik sesuai dengan kebutuhan masyarakat. Hal ini menyebabkan terjadinya kelebihan anggaran yang tak jarang menimbulkan korupsi di berbagai lini pemerintah, baik kementerian, lembaga, badan usaha, hingga pada pemerintah daerah dari kepala daerah, birokrat publik, maupun 
kepala dinas. Kebocoran anggaran ini tak hanya dari sektor belanja saja melainkan menyeluruh pula pada sektor pendapatan yang diperoleh pemerintah pusat maupun daerah.

Selain itu belanja negara dan belanja daerah belum dapat memberikan dampak pengurangan kemiskinan dan peningkatan kemakmuran rakyat. Hal ini karena kurangnya belanja modal yang dimiliki daerah untuk membangun infrastruktur untuk menghubungkan wilayah antar pulau di Indonesia, untuk memeratakan hasil pembangunan, mendorong peningkatan ekonomi masyarakat, menarik investor untuk melakukan investasi pada daerah di Indonesia. Perlu dilakukan pembuatan anggaran belanja modal yang semakin tajam pada sektor ini. Belanja modal yang tajam dapat digunakan untuk pelayanan dasar bagi masyarakat, dalam hal pendidikan, kesehatan, pelayanan sosial, dan infrastruktur. Dengan begitu infrastruktur yang dibutuhkan masyarakat akan terpenuhi sehingga ekonomi akan meningkat. Pemerintah daerah juga perlu melakukan peningkatan daya serap anggaran yang semakin besar untuk kepentingan pelayanan publik.

Dalam hal ini transparansi dan keterbukaan pemerintah dalam anggaran sangat diperlukan. Pemerintah daerah maupun pusat wajib memberikan keterbukaan akan anggaran yang telah dibuat dan besaran belanja yang digunakan. Perlu dibuat laporan pertanggungjawaban yang seluruh aktivitas pembelanjaan masyarakat dapat mengetahui untuk ikut mengawasi jalannya pembiayaan belanja yang dilakukan pemerintah. Partisipasi masyarakat dalam pengawasan kinerja pemerintah dalam pembelanjaan anggaran perlu ditingkatkan. Jangan sampai masyarakat baru ikut berpartisipasi ketika anggaran belanja yang digunakan pemerintah ditemukan telah terjadi penyelewengan anggaran. Masyarakat perlu untuk terus memantau apa yang dilakukan pemerintah dalam belanja publik.

Peningkatan kapasitas dan kapabilitas pemerintah dalam SKPD juga perlu ditingkatkan untuk melayani masyarakat dalam pelayanan publik. Pengetahuan akan kebutuhan dasar masyarakat dalam pelayanan publik perlu untuk ditingkatkan oleh pemerintah. Dengan begitu, SKPD akan mengetahui anggaran belanja yang perlu untuk ditingkatkan maupun diperbesar agar pelayanan publik bagi masyarakat terpenuhi. Dan pada akhirnya, yang 
terpenting adalah memperbaiki komposisi APBN maupun APBD dengan lebih menekankan pada kebijakan yang mendukung keberpihakan kepada masyarakat. Yaitu dengan membuat anggaran sesuai dengan kebutuhan, potensi, dan lingkungan (Sumber Daya Alam dan Sumber Daya ekonomi) serta daya dukung infrastruktur yang ada pada suatu wilayah tertentu. Jangan sampai terjadi ketimpangan antara apa yang menjadi kebutuhan pembangunan daerah dengan anggaran belanja yang dibuat oleh pemerintah, karena hal ini akan menjadi bumerang yang tentu akan merugikan masyarakat atas kebijakan yang tidak pro pada kepentingan rakyat.

\section{DAFTAR PUSTAKA}

Kabupaten Magetan. 2013. Deskripsi analisis APBD.

http://setkab.go.id/kawalapbn/penyerapananggarandanpert umbuhanekonomi/html. diakses pada 25 mei pukul 08.05

Mardiasmo. 2005. Akuntansi Sektor Publik. Yogyakarta: Penerbit Andi.

Kementerian Keuangan RI. 2014. Nota keuangan.
Perda APBD Tahun Anggaran 2014 Kabupaten Magetan.pdf

http://www.djpk.kemenkeu.go.id diakses tanggal 13 Juli 2014 pukul 9.56

http://www.bps.go.id diakses tanggal 9 Juli 2014 pukul 11.16 